\title{
Intelligence Concept: A Cross-cultural Study of University Students from The Javanese and Madurese in East Java
}

\author{
Agung Minto Wahyu \\ Fakultas Pendidikan Psikologi, Universitas Negeri Malang \\ email: agungminto98@gmail.com \\ Angger Pangestu \\ Fakultas Pendidikan Psikologi, Universitas Negeri Malang \\ email: angger.pangestu.psi17@gmail.com \\ Retno Sulistiyaningsih \\ Fakultas Pendidikan Psikologi, Universitas Negeri Malang \\ email: retno.sulistiyaningsih.fppsi@um.ac.id \\ Ninik Setiyowati \\ Education Faculty, University of Malaya, Malaysia \\ email: pva170081@siswa.um.edu.my
}

\begin{abstract}
Intelligence is often used as a benchmark to predict someone's success in the future. Therefore, intelligence is also often used as a reason for someone to label individuals who do not have the abilities that others want. Students of education faculty as prospective educators in the future have a fairly central role in providing understanding about the intelligence that students have to the parents, senior teachers, and students themselves. Before becoming an educator, education students are expected to have a good concept of intelligence so that the understanding given can be done precisely. This study aims to reveal the concepts of intelligence subjectively to the students of prospective educators from the Javanese and Madurese. The study used a qualitative research approach with a case study model that emphasized the exploration of a system that intertwined with each other. The results showed that education students who originated from Javanese and Madurese have a very diverse concept of intelligence. Despite the
\end{abstract}

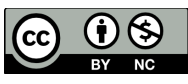

DOI: $10.19105 /$ karsa.v29i1.3379 
diverse concept of intelligence, the concept of the student intelligence of both tribes has a relation that complements each other. Students of both tribes also have the view that each individual has different intelligence. Therefore, most of the students from both tribes have been in line with Howard Gardner's multiple intelligences theory. The findings in this study are that interpersonal intelligence is considered to be the most prominent by the Madurese people, because the ability to connect with others is very high.

[Kecerdasan seringkali dijadikan tolak ukur untuk memprediksi keberhasilan seseorang di masa depan. Maka dari itu, kecerdasan juga sering dijadikan sebagai alasan seseorang untuk melakukan labelling terhadap individu yang tidak memiliki kemampuan yang diinginkan orang lain tersebut. Mahasiswa kependidikan sebagai calon pendidik di masa depan memiliki peran yang cukup sentral dalam memberikan pemahaman terkait kecerdasan yang dimiliki siswa kepada para orang tua, guru-guru senior, dan siswa itu sendiri. Sebelum terjun menjadi pendidik, mahasiswa kependidikan tentunya diharapkan telah memiliki konsep kecerdasan yang baik agar pemahaman yang diberikan tersebut dapat dilakukan secara tepat. Penelitian ini bertujuan mengungkap konsep-konsep kecerdasan secara subjektif pada mahasiswa calon pendidik dari Suku Jawa dan Suku Madura. Penelitian ini menggunakan pendekatan penelitian kualitatif dengan model studi kasus yang menekankan pada eksplorasi dari suatu sistem yang saling terkait satu sama lain. Hasil penelitian ini menunjukkan bahwa Mahasiswa Kependidikan yang berasal dari suku Jawa dan suku Madura memiliki konsep kecerdasan yang sangat beragam. Meskipun memiliki konsep kecerdasan yang beragam, konsep kecerdasan mahasiswa dari kedua suku tersebut memiliki keterkaitan yang saling melengkapi satu sama lain. Mahasiswa dari kedua suku juga memiliki pandangan bahwa setiap individu memiliki kecerdasan yang berbeda-beda, sehingga sebagian besar mahasiswa dari kedua suku telah sejalan dengan teori multiple intelligences Howard Gardner. Temuan dalam penelitian ini yaitu bahwa kecerdasan interpersonal dianggap paling utama oleh Masyarakat Madura, sebab kemampuan menjalin relasi dan berhubungan dengan orang lain sangat dijunjung tinggi.]

Keywords: intelligences; multiple intelligences; cross cultural; ethnic; Javanese; Madurese

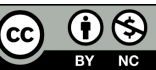

DOI: 10.19105/karsa.v29i1.3379 


\section{Introduction}

Intelligence is an interesting topic to discuss. Intelligence is often used as a measure to predict a person's future success. Moreover, intelligence is also often considered as a prestigious matter, to which many take pride in measuring the level of intelligence obtained. Apart from measuring aptitude tests, most people also see a person's intelligence in his or her achievement in school. ${ }^{1}$

Intelligence can be used by humans in sustaining life by doing self-development ${ }^{2}$. Human intelligence was divided into two. The first intelligence is potential ability defined as implicit and invisible ability and has not yet been manifested into a concrete result. This potential ability is a natural ability brought from birth. These potentials are intelligence as a general ability and talent as a special ability. Second, the actual ability defined as the explicit ability that has been manifested in various aspects of life in the form of achievement. This actual ability was derived from potential abilities that have been developed in spite of environmental impact. ${ }^{3}$

Intelligence that is one form of potential ability is defined differently by experts. According to Goddard, intelligence is a level of ability derived from someone's experience to solve the problem faced, that included with the ability to anticipate the problem to come. Thorndike defines intelligence as the ability to respond well to facts or truths. Another definition, held by Walters and Gardner, is intelligence as a set of abilities that enable the individual to solve the problem. It was similar with Flynn that defined intelligence as the ability to think abstractly and preparedness to learn from experience. Wechsler, on the other hand, defined intelligence is the ability to act directively, rationally, and effectively confront the environment. ${ }^{4}$ Shiraev and Levy

\footnotetext{
${ }^{1}$ Siwi Herlina Widiana, "Landasan Konseptual Teoritik Psikologik Dari Berbagai Teori Inteligensi," Humanitas (Jurnal Psikologi Indonesia) 6, no. 1 (2009): 56-73.

2 Purwanto. "Intelegensi: Konsep Dan Pengukurannya." Jurnal Pendidikan Dan Kebudayaan, 2010. https://doi.org/10.24832/jpnk.v16i4.479.

${ }^{3}$ Nana Syaodih Sukmadinata. Landasan Psikologi Proses Pendidikan. (Bandung: PT. Remaja Rosdakarya, 2003).

${ }^{4}$ Saifuddin Azwar, Pengantar Psikologi Inteligensi (Yogyakarta: Pustaka Belajar, 2011).
}

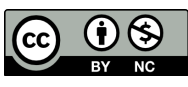

DOI: $10.19105 /$ karsa.v29i1.3379 
summarize various definitions of intelligence among the experts above as the ability to know and understand reality, the ability of knowledge and skill used for problem solving and achieving goals, and the ability to adapt in dynamic situations and conditions. ${ }^{5}$

The varying definitions of experts predisposed each person to have a different outlook on intelligence. Even Francis Galton is not finding out clearly what the definition of intelligence is. Differing points of view with each person would make a personal agreement on the concept of intelligence. ${ }^{6}$ The consensus of intelligence agreed upon by the environment would be a standard of judgment in a particular area. It's not uncommon for the standards of judgment regarding intelligence that have been shaped to be a rather irrational stigma. Phelan defines the stigma as a phenomenon that occurs when someone is given labeling, stereotyping, separation, and discriminating. ${ }^{7}$

Gardner explained that actually every human being must have an intelligence. Such intelligence comes in a different form and so does not refer only to the academic achievement. The view was now better known as the multiple intelligence theory. ${ }^{8}$ The implication in everyday life is that the multiple intelligence theory will see each human being as a unique individual. Such uniqueness results from an accumulation of the phase of life that has passed through time. ${ }^{9}$

Further, the multiple intelligence divide the forms of intelligence into nine, which are verbal-linguistic intelligence, logis-mathematical intelligence, visual intelligence, musical intelligence, kinaesthetic

\footnotetext{
${ }^{5}$ Eric B. Shiraev , and David A. Levy. "Cross-Cultural Psychology: Critical Thinking and Contemporary Applications". The Corsini Encyclopedia of Psychology, 2010. https://doi.org/10.1002/9780470479216.corpsy0243.

${ }^{6}$ Saifuddin Azwar, Op.cit., 2011.

${ }^{7}$ Teresa L. Scheid and Tony N. Brown. A Handbook for the Study of Mental Health: Social Contexts, Theories, and Systems, 2010. https://doi.org/10.1007/978-94-0074276-5_25.

${ }^{8}$ Howard Gardner. Multiple Intelligences: The Theory in Practice A Reader. (New York: Basic Books, 1993).

${ }^{9}$ Ainurrahman Hidayat, "Jatidiri Orang Madura (Vis a Vis) Industrialisasi," KARSA: Journal of Social and Islamic Culture 16, no. 2 (2009): 53-61, https://doi.org/10.19105/karsa.v16i2.105.
}

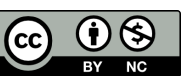

DOI: 10.19105/karsa.v29i1.3379 
intelligence, interpersonal intelligence, intrapersonal intelligence, and naturalist intelligence. Therefore, there are no human would be foolish, for each man must have the most outstanding ability that could later be called his intelligence. ${ }^{10}$

The perspective on the multiple intelligence are sometimes far beyond the grasp of ordinary people. Many people have long speculated that intelligent children are highly educated in schools especially in math subjects. ${ }^{11}$ The tendency, therefore, is that the parent will only develop a school-related side of the child's intelligence rather than the other areas. This can be a cause of psychological disturbances for children. Whereas, consistent with multiple intelligence theory that intelligence can vary, it is not even limited to the achievement of studying in school. ${ }^{12}$

The people perception was proven when at Kawasan Kaki Jembatan Suramadu Sisi Madura (KKJSM) will be built by Badan Pengembangan Wilayah Surabaya Madura (BPWS) in Bangkalan district, Madura. There were denial that was initiated by Madurese people living on the coast. In this condition, there were logic, rational, and sensible initiators from the coastal village. The reason is that the coastal region will be affected by the development of KKJSM because the house will be moved under unjust damages. Moreover, the move of the house would deprive many the majority of the family heads of fishermen of their livelihood. ${ }^{13}$

According the phenomena above, when it was viewed by the number of long years of school expectations and the average years of school contained in the human development index (IPM) based on East Java Statistical Agency (BPS) data, the rank areas in Madura tend to be low. Bangkalan District ranks to thirty-seven for the long years of school expectations category and in the ranks to thirty-six for the average years of school category from the total number of thirty-eight districts in East

\footnotetext{
${ }^{10}$ Howard Gardner, Op.cit.

${ }^{11}$ M Chatib, Orang Tuanya Manusia: Melejitkan Potensi Dan Kecerdasan Dengan Menghargai Fitrah Setiap Anak (Bandung: Kaifa, 2014).

${ }^{12}$ Viarti Eminita and Arlin Astriyani, "Persepsi Orang Tua Terhadap Kecerdasan Majemuk Anak," Pendidikan Matematika Dan Matematika 4, no. 1 (2018): 1-16.

${ }^{13}$ (Imron, 2020; Kabar Madura, 2020; Koran Madura, 2019)
}

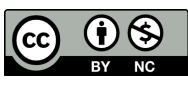

DOI: $10.19105 /$ karsa.v29i1.3379 
Java. ${ }^{14}$ In contrast with the data's condition, however, there were still others who had reasoned and rational thought in the region and were able to pull together and make aspirations related to the problems they faced, although the initiator did not have a high formal education. However, if it is attributed to multiple intelligence, the initiator can be said to have interpersonal intelligence.

On the other hand, the stigma associated with an individual's assessment of intelligence is still pretty common. The stigma tends to form a labeling. For example, a student might be considered smart if he goes to a public school, or he might be great when passing a satisfying national exam. But the stigma cannot be claimed as a true stigma. The effects such as on the suicide by junior high school student in Blitar, East Java. The news published by Kompas explains that the cause of suicide was the student fear of not being received at the favorite high school in Blitar. ${ }^{15}$ The case may happen because most people think the favorite high school as being smarter than regular high school students.

Based on the two phenomena occurring in some areas of East Java, the role of teachers is expected to be able to give an understanding to students' parents effectively regarding multiple intelligence that one of the students must have. As the first guard in giving understanding to students' parents, surely a teacher must have a good concept of judging an intelligence from a student. Thus, researchers chose student from the education faculty as research subjects that would later become future teachers. The study will subjectively expose intelligence concepts to students. The student of education faculty chosen to be the subject of research was students from the Javanese and Madurese. The selection of the two subjects was based on previously exposed phenomena.

Based on previously described background, the focus in the study was to subjectively expose intelligence concepts to students as

\footnotetext{
${ }^{14}$ (BPS Provinsi Jawa Timur, 2019)

15 Caroline Damanik, "Siswi SMP Bunuh Diri, Diduga Karena Khawatir Tak Bisa Masuk SMA Favorit," Kompas, June 2, 2018, https://regional.kompas.com/read/2018/ 06/02/15540631/siswi-smp-bunuh-diri-diduga-karena-khawatir-tak-bisa-masuk-smafavorit.
}

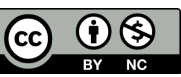

DOI: 10.19105/karsa.v29i1.3379 
prospective educators of the Javanese and Madurese. The purpose of this study is to exposure the concept of intelligence subjectively on Javanese and Madurese education students in East Java.

\section{Method}

The study conducted a qualitative research approach. Qualitative research in psychology is a method of study that describes objects of non-numerical procedure and data of psychology to explore a meaning derived from social or humanitarian issues. ${ }^{16}$ The kind of research used was qualitative research with case studies. Case study research is a research model that focuses on exploring a system that interacts with one another in an in-depth case. Case studies are also accompanied by deep data digs that involve a wide range of rich information sources of context. ${ }^{17}$

The subject in the research was university students from Faculty of Education Universitas Negeri Malang that would be prospective educators. The students were from Javanese and Madurese with total number were three for each tribe. The research location was in Universitas Negeri Malang.

The data-collection technique used deep using semi-structured interviews. The description of semi-structured interviews, the first of which was to use open questions, but there remained a limit to theme and conversation lines. The second was to have a predictable duration of the interview. The third was a guideline for a referral interview. ${ }^{18}$

The next step was data analysis to sequence data, organize them to form a pattern, classify, make the category and basic exposures. ${ }^{19}$ Data analysis in the study involved using qualitative data analysis

\footnotetext{
${ }^{16}$ Fattah Hanurawan. Metode Penelitian Kualitatif Untuk Ilmu Psikologi. (Surabaya: KPKM Universitas Airlangga, 2012).

${ }^{17}$ J. W. Creswell. Research Design: Qualitative, Quantitative, and Mixed Methods Approaches. (New Delhi: Sage Publications, 2013).

${ }^{18}$ Haris Herdiansyah. Metodologi Penelitian Kualitatif dalam Ilmu Psikologi. (Jakarta: Salemba Empat, 2015).

${ }^{19}$ Michael Quinn Patton. Qualitative Research and Evaluation Methods. Qualitative Inquiry, (2002). https://doi.org/10.2307/330063.
}

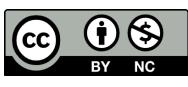

DOI: $10.19105 /$ karsa.v29i1.3379 
models Miles and Huberman, which consists of data collection, data reduction, data presentation, and data verification. ${ }^{20}$

Testing the validity of the data in this study was done using triangulation. Triangulation is a method used to see the consistency of evidence showing (response). ${ }^{21}$ The triangulation used in this research is the source and inter-researcher triangulation. Source triangulation was performed by obtaining data from different sources using the same collection technique. On the other hand, triangulation between researchers was conducted by using more than one person in data collection and analysis process. ${ }^{22}$

\section{Result}

\section{The Concept of Intelligence in The Students Comes from Javanese}

Intelligence was understood differently from each education student from the Javanese. The first subject defined intelligence as the ability to solve the problem within itself and the ability to implement the solutions created. Furthermore, the characteristics of smart children were persistent and brave to move out from the comfort zone.

On the other hand, a second subject defined intelligence as much as three statements, first intelligence as the ability to think and make decisions quickly and precisely. Second, intelligence was the ability to make ideas then could communicate with others. Third, intelligence was the ability to communicate well.

The third subject defined intelligence as a speed which was possessed by a person in capturing a new information. In addition to the speed at which a person was able to assimilate the information he received. Thus, all three subjects agreed that intelligence could not be attributed only to the value one receives from school.

\footnotetext{
${ }^{20}$ M. B. Miles, A. M. Huberman, and J. Saldana. Qualitative Data Analysis: A Methods Sourcebook. (USA: Sage Publications, 2014).

21 Ibid.

22 Mudjia Rahardjo, “Triangulasi Dalam Penelitian Kualitatif," UIN Maulana Malik Ibrahim Malang, 2010, https://www.uin-malang.ac.id/r/101001/triangulasi-dalampenelitian-kualitatif.html. (accessed May 4, 2020).
}

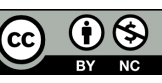

DOI: $10.19105 /$ karsa.v29i1.3379 
The subject explained that someone intelligent depend on the standpoint of how to evaluate it. Each individual had a unique within himself that could be developed. It also signified that the intelligence of each individual could not be equally evaluated. Therefore, both parents and teachers should be able to have understanding related the intelligent so they could support and develop the intelligence that each student had.

The first subject explained intelligence as the result of interaction between genetic factors and environmental factors. Environmental factors, however, were an even greater factor than genetic ones. According to first subject, the dominant environmental factor could be seen from someone IQ level that having a little influence in the development of intelligence if it did not have support from the environment. On the other hand, the other two subjects were more likely to think that intelligence was a product of someone environment. The argument was based on the fact that many children were born from intelligent parent, but the children did not necessarily have the same intelligence as the parent. That might happen because even if a parent was smart, but if it is unable to provide an environment that supports a child to grow, then the child would not be able to become intelligent like the parent.

The second subject had a distinct view that there was a distinct definition between intelligent and smart. A smart child might not be smart, but an intelligent child was certainly smart. The subject explained that a clever child was someone with the ability to understand and make new ideas, but he was unable to communicate to others. While intelligence was defined as the ability to understand and create new ideas, while being able to communicate to others. The subject also argued that intelligence divided into three kinds, intellectual intelligence, emotional intelligence, and spiritual intelligence.

Related to the intelligence, the second subject explained that if any individual had the ability to present his or her ideas in writing, but was unable to communicate them to others, then the individual might be said to be smart person and did not mention as an intelligent person.

As the latter suggests, the second subject also claimed that individuals who had the academic competence of mathematics, physics, chemistry could be said to be clever, but they were not intelligent. The

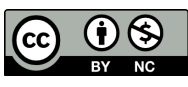

DOI: 10.19105/karsa.v29i1.3379 
subject had a reason that such those individuals were only capable in using the abilities that they had for themselves. On the other hand, the third subject actually assumed that the academic performance of an individual could be said as an intelligence because it was kind of the abilities that might be differ someone to others.

The ability in the drawing in which the process of imagining the patterns could be called as intelligence. The first subject stated that the reason for such ability could be called as intelligence was because the individual meant to had been able to recognize its potential and passion and thus be optimized.

The subjects shared a similar perspective of individuals who had musical abilities. The perspective claimed that such individuals were intelligent, even though the individuals were inadequate for a good school course. It was because of the individual ability in implementing what had been learned and could be mastered on those abilities.

All three subjects regarded individuals who had abilities in the art of dance and exercise as intelligent persons. It caused of the kind of abilities could be explored and increased continually. Although they were not kind of academic ability, these abilities could produce achievements for individuals and also provided a provision for an individual future.

The subject of education students from the Javanese agreed that individuals who had a good communication skill, made a broad connection, and were proficient in lobbying others were kind of intelligent persons. It caused of the abilities could be used directly to convey their aspirations or ideas to others. Therefore, these abilities could be seen by others.

Furthermore, the second subject regarded that individuals who had a good ability to recognize themselves, control themselves and manage their emotions, could be said to be intelligent. The subject assumed that without this kind of ability, it was easy for an individual to feel insecure, which lead to someone difficulty in upgrading himself according to his own passion.

The three subjects also had the same view that individuals who had the expertise to care for animals and care for various plants could

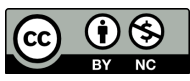

DOI: $10.19105 /$ karsa.v29i1.3379 
be regarded as intelligent person. Even though the person had no a good academic performance. By these kinds of abilities, individual had the ability to explore his strengths that made individual had a willingness to learning continually and sustainability.

The three subjects were in the opinion that teachers were often giving labelling to their students. The labelling was given both intentionally and unintentionally. Giving labelling was such kind of harmful thing in the school environment because it broke the code of ethics and could make students lose confidence in performing the ability. In addition, there were still many of teachers who insisted that students should get a good grade in the subject they taught. Therefore, teachers should be able to understand what was becoming both the strength and weaknesses of the students. By having the knowledge, it was also expected that teachers would be able to give a well support to the students in order to develop and jumped-up students' abilities.

Teachers as persons who entrusted by parents to educate their children, are expected to be able to give their parents perspectives in order to understand that every child had the different intelligences. The understanding could help parents in giving instructional at home according to children ability. This made a home as a convenient place for children to learn because they had the support from parents.

Previously, home was considered as an uncomfortable place for children to study. It was caused of parents tend to push their children in doing what parents' willingness. On the other hand, the understanding of parents related kinds of intelligences that was lacking had effect in giving an unsuitable learning approaches for the child.

\section{The Concept of Intelligence in The Students Comes from Madurese}

Intelligence was variously defined by the subject of education student who came from Madura. The first subject had the opinion that each person had his own intelligence, and it was not measured from just one point of view. Then, the characteristics of someone intelligent could be seen in the capability in applying abilities.

In contrast with the first subject, the second defined intelligence as the individual ability to provide solutions to the problems faced, as well as the ability to adapt to the environment. Furthermore, to be

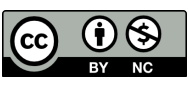

DOI: 10.19105/karsa.v29i1.3379 
intelligent, someone need to apply the existing science and theory. The characteristics of an intelligent person might be known by the habits of discipline and active in the environment in which someone live.

The third subject explained that intelligence was made up of several kinds. Furthermore, intelligence was not only judged by the ability of the brain in both academic and non-academic matters, but it could also be judged on his mental capacity to think through any event at hand. Based on the subject's exposure, academic performance could not be quantifiable in defining intelligence.

According to the second subject, a person's abilities that he showed in class was a form of intellectual intelligence. Moreover, intelligence could be trained and learned. A person's abilities in the class were only as clever criteria, but it was not as intelligent criteria. Smart people would only become apathetic if they could not offer a solution to the problems of others. Intelligence could be obtained through study, whereas in order to achieve an intelligence, a person must be able to apply the knowledge he had first.

The first subject explained that intelligence could come from two factors: genetic and environmental factors. But he felt that the environmental factors were the most affected. The other two subjects also shared the same opinion as the first, in which they regarded the environmental factors that most influence intelligence. According to the three subjects, environmental factors were a source of learning to solve problems within the environment.

Based on a definition established by all three subjects, the first subject exposed that a person who had the ability to convey what he or she was known to be an intelligence. The subjects felt that those who had these abilities were something important to possess. The third subject had the same opinion, in which public speaking skills or verbal skills were one of the cleverness a person had. Contrary to the opinions of the two subjects above, the third argued that verbal ability was not as smart category if it was not implemented in person life. The ability could be acquired from study and practice.

Furthermore, the first subject explained that someone who was prone to imagination or can visualize a form or pattern in their visual

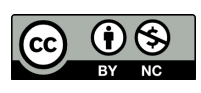

DOI: $10.19105 /$ karsa.v29i1.3379 
image is intelligent person. According to the first subject, the habit of imagining can sharpen someone cognitive abilities. In contrast with the first subject, the second subject viewed that imagination cannot be said to be clever if what he imagined in a visual could not produce a work or an output from his imagination. Third subject added that when an imagination having by person was accompanied by the realization, it could be said as intelligence.

All three subjects then agreed that those who had musical skills were, in a way, was intelligent people. The first subject saw that skill in music required a special technique that only great people could perform. In addition, the second subject argued that playing music required emotional intelligence and intellectual intelligence. Emotional intelligence was required because music required patience and calmness, while intellectual intelligence was required when someone wanted to develop or improvise a song.

All three subjects shared the same opinion toward people who had talents and abilities in the sport because physical abilities could be involved as part of intelligence. They agreed that every person had his talents and abilities. The second subject added that in exercising, someone would practice direct knowledge and sports theories.

The first subject argued that ability to make contacts was part of verbal intelligence. People who could develop their social skills with both the environment and the organization was intelligent people. In line with the opinion of the first subject, the second subject also said that the ability to make contact with others could be said to be a general intelligence which already included emotional, intellectual, and spiritual intelligence. Emotional intelligence was used when someone choose and adjusts to another. Then, how a person solved problems in his ward was part of intellectual intelligence, as well as spiritual intelligence could be judged when a person was ethical in his social environment.

Moreover, there were kind of people who had adaptive and selfcomprehending ability. According to the first subject, these abilities included self-management, managing stress, and resolving problems of their own. It was the most basic ability a person had to possess to be said to be intelligent. On the other hand, the second and third subjects argued

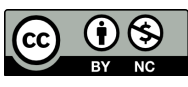

DOI: 10.19105/karsa.v29i1.3379 
that people who were only capable of pleasing themselves included selfish characteristic could not be called as part of intelligence.

Then, the first and second subjects agreed that someone interest in caring for animals and the environment could be called intelligence. The first subject added that when someone just interested in animal and environment without gave an intention to the interest so that could not be said as an intelligence. Intelligent persons would be able to execute and implement their interest in raising animals and planting the crops. On the other hand, intelligence derived from a genetic factor did not require an interest in being intelligent on a matter, because it had arisen in a person by itself. However, intelligence influenced by environmental factors is likely to require interest. The second subject said that a person who loved nature and environment felt into the category of emotional intelligence. Contrary to the opinions of the two previous subjects, the third said that anyone could maintain an animal or an environment so it could not be said as an intelligence.

Based on the subject's exposure to some of the intelligences, it was expected that parents did not give the labelling related the intelligence based on the scores that students got from the school. As prospective teachers and educators, the first subject said that giving socialization was one of the ways might be effective to make parents understand that intelligence was not just the scores of the class. Additionally, extracurricular scores were deemed necessary to help parents understand the talents and abilities of their children. Parents were suggested to direct children in improving their talents and interests.

According to the first subject, Madurese people highly esteem family ties and cooperation, so social intelligence was highly valued. The first subject agreed with the Madurese people value in regard to intelligence. He felt that social relationships and interactions were essential in adjusting to the environment.

According to second subject, the most important intelligence was the ability in keeping the relationship, interpersonal intelligence, and naturalistic intelligence. The Madurese people listen to religious teachers more than school teachers, so that Madurese had a preference in attitude than knowledge. Furthermore, according to the Madurese, by

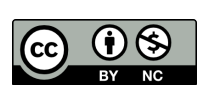

DOI: $10.19105 /$ karsa.v29i1.3379 
performing attitude first, people could be said that they had three kinds of intelligences, emotional, intellectual, and spiritual intelligence.

The third subject agreed with the previous subject's opinion on the opinion of the Madurese perspective. The Madurese people generally think that those who were good at academic matters were not necessarily smart if they did not have a good social relationship with the community and the environment. It meaned that the cultures associated with civility are still valid and are worth more than cleverness. Thus, it might be concluded that interpersonal intelligence is the most desirable kind of intelligence in the Madurese because interpersonal intelligence is the ability to understand and communicate with others, to shape and maintain relationships, and to know the various roles that exist in a social environment.

\section{Discussion}

Each student from both tribes have varying definitions of intelligence. This is natural because the experts also define intelligence in a variety of ways. The 1921 symposium on intelligence that discussed intelligence produced twelve different definitions from experts. ${ }^{23}$

Alfred Binet defines intelligence as the three components, which are the ability to focus on problems currently faced (direction), the ability to adapt and be flexible in facing a problem (critism), and the ability to criticize himself and others (critism). Stern agrees with the adaptive component of the Binet, that is, intelligence is the general capacity of an individual to adapt to the situation at hand. Wechsler defined intelligence as the ability to act directively, rationally, and effectively confront the environment. ${ }^{24}$

The definition of intelligence from both Javanese and Madurese students have been in line with definitions presented by experts. Some even have similarities between one another. Experts also acknowledge that it is very difficult to come up with the same consensus regarding the

${ }^{23}$ Anita E. Woolfolk and Lorraine McCune Nicolich, Educational Psychology for Teachers (New Jersey: Prentice Hall Inc, 1984).

${ }^{24}$ Saifuddin Azwar, Op.cit.

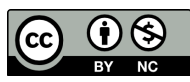

DOI: $10.19105 /$ karsa.v29i1.3379 
definition of intelligence. Thus, differences in the definition of intelligence are most likely due to their individual perspectives. ${ }^{25}$

Students from both tribes also often link intelligence into the three forms of intellectual, emotional, and spiritual intelligence. Intellectual intelligence is an individual capacity that can be used to analyse, understand causality relationships, think abstractly, use language, and visualize and comprehend things. ${ }^{26}$ On the other hand, Goleman as the one who popularizes the term emotional intelligence, defines emotional intelligence as a distinct advantage of the individual to motivate himself, organize emotional and mental states, and be able to stand in the midst of failure. These abilities are identical to intrapersonal intelligence in multiple intelligence theory. ${ }^{27}$ Spiritual intelligence has a role as the ultimate foundation for the use of the intellectual and emotional intelligence of humans. ${ }^{28}$

Some students from both tribes also had different views of intelligence and cleverness. Intelligence is defined as a capacity that someone can see and has a real effect on others. Cleverness, however, is a skill that can only be enjoyed by itself. The regard coincides with Taufik's claim that there is a distinction between intelligence and cleverness. According to Taufik, intelligence requires diligent and discipline character to know a new information that is more textual, whereas cleverness tends to be natural that can lead an individual to be able to interpret information concurrently and more creatively. ${ }^{29}$

Some Javanese students thought that a person's intelligence was pure a product of the environments. This such a view is suitable with the Thomson's view that intelligence is not only depends on genetic factors,

\footnotetext{
${ }^{25}$ Purwanto, Op.cit.

${ }^{26}$ Stephen R. Covey. The 8th Habit: From Effectiveness to Greatness. (New York: Free Press, 2004).

${ }^{27}$ D. Goleman. Emotional Intelligence. (New York: Bantam Books, 1995).

28 Danah Zohar and Ian Marshall. Spiritual Capital: Wealth We Can Live By. (California: Berrett-Koehler Publishers, 2004).

29 Miskudin Taufik. "Pintar Dan Cerdas Itu Beda." (Inspektorat Jenderal Kemendikbud, 2019). https:/itjen.kemdikbud.go.id/public/post/detail/pintar-dancerdas-itu-beda. (accessed May 3, 2020)
}

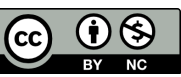

DOI: 10.19105/karsa.v29i1.3379 
but also on opportunities to learn by the environment. Therefore, children who are smarter than others are not due to genetic factors but because such intelligent children have more opportunity and support from their environment to learn. ${ }^{30}$

On the other hand, students from the Madurese believe that intelligence can be influenced by genetic and environmental factors. That view coincides with Spearman's claim that intelligence is resulted from an interaction of genetic and environmental factors. Spearman calls it the two factors, which is the general factor (g) underlying the everyday conduct and the specific factor (s) underlying certain behaviours that are unique for each individual. The $g$ factor comes from genetics, while the s factor comes from the environment. ${ }^{31}$

The opinion of the students from both tribes agreed that each individual must have different intelligences. They are relevant to Gardner's view of what strongly says that each human is intelligent. Each human has a unique kind of intelligence that differs from others. Starting from the view, Gardner spawns the multiple intelligence theory. According Gardner theory, it could be said that the intelligence of a human being is divided into nine different forms of intelligence. ${ }^{32}$

Students from Javanese believe that individuals who have the ability to transmit ideas into written form may be said to be clever, but he is not intelligent. Such opinions differ with the multiple intelligence, as in the theory, the ability to write can be classified into the form of linguistic intelligence. Gardner defines linguistic intelligence as the ability to use and process words effectively, both oral and written. ${ }^{33}$

Some students from the Javanese have a view that academical numerical lessons are kinds of intelligence. In the other hand, students from the Madurese thought that such ability was a cleverness. If the thought and opinion related to multiple intelligence theory, it is

\footnotetext{
${ }^{30}$ Anne Anastasi and Susana Urbina, Psychological Testing. Seventh Edition (Upper Saddle River, NJ: Prentice Hall Inc., 1997).

${ }^{31}$ Robert J. Gregory, Tes Psikologi: Sejarah Prinsip dan Aplikasi (Jakarta: Erlangga, 2014).

${ }^{32}$ Howard Gardner. Frames of Mind: The Theory of Multiple Intelligences. (New York: Basic Books, 2011).

${ }^{33}$ Ibid.
}

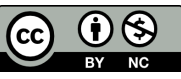

DOI: 10.19105/karsa.v29i1.3379 
classified as a mathematical intelligence. The intelligence of the mathematics is the ability to solve the problems of numbers and calculations, as well as logical and scientific thought. ${ }^{34}$

Students from both tribes also agree that individuals who have the ability in imagining pattern then manifest it in picture form (it would be better if the imagination could be realization in a real output) as called as intelligent person. In the theories of multiple intelligence, such ability is involved in the spatial intelligence that allows individuals to imagine shapes of geometry or three dimensions easily. ${ }^{35}$

Another form of intelligence according to the multiple intelligence theory is the musical intelligence. Musical intelligence is the ability to develop, express, and enjoy musical and voice forms, as well as the ability to play instruments, sing, create and enjoy songs. ${ }^{36}$ Students of both tribes are also in line with the view that the ability to play music of an individual can be regarded as an intelligence.

The next skill regarded by the students of both tribes as the ability to dance (both traditional and modern) and exercise. Such views are in line with the kinesthetics intelligence in multiple intelligence theory. Kinesthetics intelligence is the ability to develop skills that deal with physical movements well. ${ }^{37}$

Abilities associated with keeping relations, communication, public speaking, and negotiation are kinds of intelligence. The student from both tribes have the same opinion related these abilities. The abilities may be called as interpersonal intelligence. As a form of the multiple intelligence theory, interpersonal intelligence is identic with the

\footnotetext{
${ }^{34}$ S. Rahmah. "Teori Kecerdasan Majemuk Howard Gardner Dan Pengembangannya Pada Metode Pembelajaran Pendidikan Agama Islam Untuk Anak Usia Sekolah Dasar." Jurnal Pendidikan Agama Islam 5, no. 1 (2008)

35 Ibid.

${ }^{36}$ Howard Gardner, Op.cit

${ }^{37}$ Phyllis K. Adcock. "The Longevity of Multiple Intelligence Theory in Education." Delta Kappa Gamma Bulletin 80, no. 4 (2014): 50-57.
}

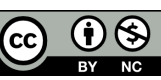

DOI: 10.19105/karsa.v29i1.3379 
ability to respond, understand and establish good relationships with others. ${ }^{38}$

Students from the Javanese view that ability to understand oneself can be regarded as an intelligence. Similarly, students from the Madurese view self-understanding as a fundamental intelligence that people must have. The multiple intelligence theory views that ability as an intrapersonal ability that defines as the ability to understand the feelings and motivation of oneself. ${ }^{39}$

The ability to maintain animals and care for plants was agreed upon by Javanese student as an intelligence, while one of Madurese students stated that it is not an intelligence because it could be committed by all people. By referring to the multiple intelligence claims, those abilities can be categorized as natural intelligence. Natural intelligence is identical ability to be care and be sensitive to the natural world and other living things (plants and animals). Therefore, this ability can be regarded as an intelligence because not all humans possess such abilities. ${ }^{40}$

Unique findings in this study suggest that in the Madurese are highly value the ability to make connections, understand and communicate with others around them. The findings are in line with the findings of Santrock that the true intelligence is the ability to communicate information verbally so that it can be used to adapt to the environment and experience of daily life. ${ }^{41}$ The findings also line up with studies that suggest that Madurese prefer to communicate information openly through verbal communication. Though it is bandaged with a slightly stiff accent, the Madurese had a highly valued

\footnotetext{
${ }^{38}$ E Barrington, "Teaching to Student Diversity in Higher Education: How Multiple Intelligence Theory Can Help," Teaching in Higher Education 9, no. 4 (2004): 421434.

39 Ami C. Brualdi Timmins. "Multiple Intelligences: Gardner's Theory." Practical Assessment, Research, and Evaluation 5, no. 10 (1996): 1-3.

${ }^{40}$ Adcock, Op.cit. ; Barrington, Op.cit. ; Timmins, Op.cit.

${ }^{41}$ John W. Santrock. Life-Span Development (13th Ed.). (New York: McGraw-Hill, 2017).
}

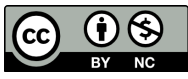


mutual character. ${ }^{42}$ Furthermore, these natural characteristics of Madurese are more likely to give rise to natural attitudes and behaviour that express of their heart. ${ }^{43}$

The multiple intelligence theory has been able to answer unequivocally doubts about intelligence shared by each individual. ${ }^{44}$ The claim that there is no human without intelligence requires the constant phenomenon of labelling, especially in the school environment, must be suppressed. Negative labelling would cause an individual to perceive himself as the other person said ${ }^{45}$ It will influence individual self-concepts to become more negative. The more specific studies claim that the most disconcerting aspect of concept toward labelling is the body image and social self. ${ }^{46}$

Lack in understanding kinds of intelligent make parents have often led to insist on their own willingness without considering the children kinds of different abilities. This kind of communication pattern would lead the children in develop, improve, and jump-up their potential. Furthermore, such communication patterns make children prone to feel stress, insecure, and discomfort in doing activities at home. ${ }^{47}$ Avoiding the effects, parents can use two-way communication

${ }^{42}$ Isti Qamariah, La Ode Jumaidin, and Sutiyana Fachruddin. "Budaya Komunikasi Etnis Madura Dalam Kehidupan Sosial Kelurahan Mata Kota Kendari." Jurnal Penelitian Kajian Ilmu Komunikasi Dan Informasi 1, no. 2 (2016): 1-15.

43 Ainurrahman Hidayat, "Karakter Orang Madura Dan Falsafah Politik Lokal," KARSA: Journal of Social and Islamic Culture 15, no. 1 (2009): 1-14, https://doi.org/ 10.19105/karsa.v15i1.109.

${ }^{44}$ Gardner, Op.cit.

45 Kushendar dan Aprezo Pardodi Maba. "Bahaya Label Negatif Terhadap Pembentukan Konsep Diri Anak Dengan Gangguan Belajar.” Nidhomul Haq 2, no. 3 (2017): 106-13.

46 Nugrahaeni, Sri Devi Eka, Sidik Permana, Rahma Sayyida Hilmia, and Mela Darmayanti. "Fenomena Labelling Dan Self-Concept Siswa." Edutech 18, no. 3 (2019): 277-88.

${ }^{47}$ Ahmad Afif and Fajriani Kaharuddin, "Perilaku Belajar Peserta Didik Ditinjau Dari Pola Asuh Otoriter Orangtua," Jurnal Pendidikan Dasar Islam 2, no. 2 (2015): 287300.

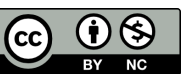

DOI: 10.19105/karsa.v29i1.3379 
to give their children an opportunity to express what they want. It is more effective to establish positive childhood behaviour in the future.$^{48}$

Students from both tribes also revealed that teachers were expected to be a mediator to communicate to parents that each child have different intelligences. An intense communication developed between parents and teachers will make it easier for sharing the children development. It will be easier to teachers in giving the view that each child has different intelligence, thus, parents can change their regard of their children abilities. ${ }^{49}$

\section{Conclusion}

Students from the Javanese and Madurese came to have varying degrees concept of intelligence. Though differing concepts of intelligence, they are intertwined with one another. Javanese students define intelligence as the ability to solve problems, ability to locate and implement appropriate solutions, ability to make decisions, ability to communicate, and ability to capturing information rapidly. On the other hand, the Madurese students define intelligence as the ability to think and to find solutions to the problems faced, and the ability to adapt. In addition, students from both tribes also viewed intelligence and cleverness as a different matter.

Some Javanese students hold the view that intelligence is pure the product of its environment, while Madurese students view it as the result of an interaction between genetic and environmental factors.

Both the Javanese and the Madurese students agree with the majority of the multiple intelligence theory view that individuals have different intelligences. However, there is a little difference opinion from

\footnotetext{
48 Rio Ramadhani "Komunikasi Interpersonal Orang Tua Dan Anak Dalam Membentuk Perilaku Positif Anak Pada Murid di SDIT Cordova Samarinda." EJournal Ilmu Komunikasi 1, no. 3 (2013): 112-21.; Yohana Susetyo Rini. "Komunikasi Orangtua-Anak Dalam Pengambilan Keputusan Pendidikan." Jurnal Interaksi 3, no. 2 (2014): 112-22.

${ }^{49}$ Mustika Chairani, Ida Wiendijarti, and Dewi Novianti. "Komunikasi Interpersonal Guru Dan Orang Tua Dalam Mencegah Kenakalan Remaja Pada Siswa (Studi Deskriptif Pada Siswa Kelas XI SMA Kolombo Sleman).” Jurnal Ilmu Komunikasi 7, no. 2 (2009): 143-52.
}

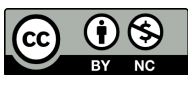

DOI: $10.19105 /$ karsa.v29i1.3379 
Javanese that consider mathematics to be a cleverness, it is not kind af intelligence.

On the other hand, students of the Madurese also have a similar view to the multiple intelligence theory. Although, there are some kind of intelligence that has not yet be regarded as an intelligence as mathematics, intrapersonal, and spatial-visual because these have no clear output. These intelligences are involved in the kind of intelligence if the specific outputs are produced.

\section{Bibliography}

Adcock, Phyllis K. "The Longevity of Multiple Intelligence Theory in Education." Delta Kappa Gamma Bulletin 80, no. 4 (2014): 5057. https://www.proquest.com/openview/511b4473e7ad2fb644da a644289bdf5b/1?pq-origsite $=$ gscholar\&cbl $=47978$.

Afif, Ahmad, and Fajriani Kaharuddin. "Perilaku Belajar Peserta Didik Ditinjau Dari Pola Asuh Otoriter Orangtua." Auladuna: Jurnal Pendidikan Dasar Islam 2, no. 2 (2015): 287-300. http://journal. uin-alauddin.ac.id/index.php/auladuna/article/view/883.

Anastasi, Anne, and Susana Urbina. Psychological Testing. Seventh Edition. Upper Saddle River, NJ: Prentice Hall Inc., 1997.

Azwar, Saifuddin. Pengantar Psikologi Inteligensi. Yogyakarta: Pustaka Belajar, 2011.

Barrington, E. "Teaching to Student Diversity in Higher Education: How Multiple Intelligence Theory Can Help." Teaching in Higher Education 9, no. 4 (2004): 421-434. https://doi.org/10.1080/ 1356251042000252363.

BPS JawaTimur. "Indeks Pembangunan Manusia (IPM) Jawa Timur Tahun 2018," 2019.

Chairani, Mustika, Ida Wiendijarti, and Dewi Novianti. "Komunikasi Interpersonal Guru Dan Orang Tua Dalam Mencegah Kenakalan Remaja Pada Siswa (Studi Deskriptif Pada Siswa Kelas XI SMA Kolombo Sleman)." Jurnal Ilmu Komunikasi 7, no. 2 (2009): 14352. https://doi.org/10.31315/jik.v7i2.17.

Chatib, M. Orang Tuanya Manusia: Melejitkan Potensi Dan Kecerdasan Dengan Menghargai Fitrah Setiap Anak. Bandung:

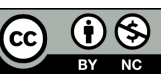

DOI: 10.19105/karsa.v29i1.3379 
Kaifa, 2014.

Covey, Stephen R. The 8th Habit: From Effectiveness to Greatness. New York: Free Press, 2004.

Creswell, JW. Research Design: Qualitative, Quantitative, and Mixed Methods Approaches. New Delhi: Sage Publications, 2013.

Damanik, Caroline. "Siswi SMP Bunuh Diri, Diduga Karena Khawatir Tak Bisa Masuk SMA Favorit." Kompas, June 2, 2018. https://regional.kompas.com/read/2018/06/02/15540631/siswismp-bunuh-diri-diduga-karena-khawatir-tak-bisa-masuk-smafavorit.

Eminita, Viarti, and Arlin Astriyani. "Persepsi Orang Tua Terhadap Kecerdasan Majemuk Anak." Fibonacci: Pendidikan Matematika dan Matematika 4, no. 1 (2018): 1-16. https://doi.org/10.24853/ fbc.4.1.1-16

Gardner, H. Frames of Mind: The Theory of Multiple Intelligences. New York: Basic Books, 2011.

Gardner, Howard. Multiple Intelligences: The Theory in Practice A Reader. New York: Basic Books, 1993.

Goleman, D. Emotional Intelligence. New York: Bantam Books, 1995. Gregory, Robert J. Tes Psikologi: Sejarah Prinsip dan Aplikasi. Jakarta:

Erlangga, 2014.

Hanurawan, Fattah. Metode Penelitian Kualitatif Untuk Ilmu Psikologi. Surabaya: KPKM Universitas Airlangga, 2012.

Herdiansyah, Haris. Metodologi Penelitian Kualitatif untuk Ilmu Psikologi. Jakarta: Salemba Empat, 2015.

Hidayat, Ainurrahman. "Jatidiri Orang Madura (Vis a Vis) Industrialisasi." KARSA: Journal of Social and Islamic Culture 16, no. 2 (2009): 53-61. https://doi.org/10.19105/karsa.v16i2.105. Hidayat, Ainurrahman. "Karakter Orang Madura dan Falsafah Politik Lokal." KARSA: Journal of Social and Islamic Culture 15, no. 1 (2009): 1-14. https://doi.org/10.19105/karsa.v15i1.109.

Imron. "Ganti Rugi Lahan Murah, Warga Madura Tolak Program BPWS," 2020. https://portalmadura.com/ganti-rugi-lahan-murahwarga-madura-tolak-program-bpws-223014/.

Kabar Madura. "Warga Labang Tolak Pembangunan Wisata KKSJM." 2020. https://kabarmadura.id/warga-labang-tolak-pembangunan-

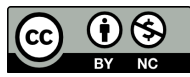

DOI: $10.19105 /$ karsa.v29i1.3379 
wisata-kksjm/.

Koran Madura. "BPN Bangkalan dan BPWS 'Merayu', Warga Tetap Tolak Pembebasan Lahan di Dusun Sekarbunguh." 2019. https://www.koranmadura.com/2019/08/bpn-bangkalan-danbpws-merayu-warga-tetap-tolak-pembebasan-lahan-di-dusunsekarbunguh/.

Kushendar, and Aprezo Pardodi Maba. "Bahaya Label Negatif Terhadap Pembentukan Konsep Diri Anak Dengan Gangguan Belajar.” Nidhomul Haq 2, no. 3 (2017): 106-13. https://doi.org/ 10.31538/ndh.v2i3.27.

Miles, M.B., A.M. Huberman, and J. Saldana. Qualitative Data Analysis: A Methods Sourcebook. USA: Sage Publications, 2014. Nugrahaeni, Sri Devi Eka, Sidik Permana, Rahma Sayyida Hilmia, and Mela Darmayanti. "Fenomena Labelling dan Self-Concept Siswa." Edutech 18, no. 3 (2019): 277-88. https://ejournal.upi. edu/index.php/edutech/article/view/17546.

Patton, Michael Quinn. Qualitative Research and Evaluation Methods. Qualitative Inquiry, 2002. https://doi.org/10.2307/330063.

Purwanto. "Intelegensi: Konsep dan Pengukurannya." Jurnal Pendidikan dan Kebudayaan 1, no. 4 (2010): 477-85. https://doi. org/10.24832/jpnk.v16i4.479.

Qamariah, Isti, La Ode Jumaidin, and Sutiyana Fachruddin. "Budaya Komunikasi Etnis Madura dalam Kehidupan Sosial Kelurahan Mata Kota Kendari." Jurnal Penelitian Kajian Ilmu Komunikasi dan Informasi 1, no. 2 (2016): 1-15. https://doi.org/10.52423/ jikuho.v1i2.1429.

Rahardjo, Mudjia. "Triangulasi dalam Penelitian Kualitatif." UIN Maulana Malik Ibrahim Malang, 2010. https://www.uinmalang.ac.id/r/101001/triangulasi-dalam-penelitiankualitatif.html.

Rahmah, S. "Teori Kecerdasan Majemuk Howard Gardner dan Pengembangannya pada Metode Pembelajaran Pendidikan Agama Islam Untuk Anak Usia Sekolah Dasar." Jurnal Pendidikan Agama Islam 5, no. 1 (2008):89-110. http://digilib. uinsuka.ac.id/8759/1/SITI\%20RAHMAH\%20TEORIKECERDA

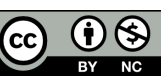

DOI: 10.19105/karsa.v29i1.3379 
SAN\%20MAJEMUKHOWARD\%20GARDNER\%20DAN\%20 PENGEMBANGANNYA\%20PADA\%20METODE\%20PEMB ELAJARAN\%20PENDIDIKAN\%20AGAMA\%20ISLAM\%20 UNTUK\%20ANAK\%20USIA\%20SEKOLAH\%20DASAR.pdf. Ramadhani, Rio. "Komunikasi Interpersonal Orang Tua Dan Anak dalam Membentuk Perilaku Positif Anak Pada Murid di SDIT Cordova Samarinda." EJournal Ilmu Komunikasi 1, no. 3 (2013): 112-21. https://ejournal.ilkom.fisip-unmul.ac.id/site/?p=865.

Rini, Yohana Susetyo. "Komunikasi Orangtua-Anak Dalam Pengambilan Keputusan Pendidikan." Jurnal Interaksi 3, no. 2 (2014): 112-22. https://ejournal.undip.ac.id/index.php/interaksi/ article/viewFile/8777/7103.

Santrock, John W. Life-Span Development (13th Ed.). New York: McGraw-Hill, 2017.

Scheid, T. L., and E.R. Wright, eds. A Handbook for the Study of Mental Health: Social Contexts, Theories, and Systems (3rd ed.). Boston: Cambridge University Press, 2017. https://psycnet.apa.org/ record/2017-30381-000.

Shiraev, Eric B., and David A. Levy. Cross-Cultural Psychology: Critical Thinking and Contemporary Applications. The Corsini Encyclopedia of Psychology. Boston: Allyn \& Bacon, 2010. http://www.umpalangkaraya.ac.id/dosen/dwisariusop/wpcontent/ uploads/2016/11/Cross_Cultural_Psychology_Critical_Thinking and_Contemporary_Applications_Fourth_Edition.pdf.

Sukmadinata, and Nana Syaodih. Landasan Psikologi Proses Pendidikan. Bandung: PT. Remaja Rosdakarya, 2003.

Taufik, Miskudin. "Pintar dan Cerdas Itu Beda." Inspektorat Jenderal Kemendikbud, 2019. https://itjen.kemdikbud.go.id/public/post/ detail/pintar-dan-cerdas-itu-beda.

Timmins, Ami C. Brualdi. "Multiple Intelligences: Gardner's Theory." Practical Assessment, Research, and Evaluation 5, no. 10 (1996): 1-3. https://scholarworks.umass.edu/pare/vol5/iss1/10.

Widiana, Siwi Herlina. "Landasan Konseptual Teoritik Psikologik Dari Berbagai Teori Inteligensi." Humanitas (Jurnal Psikologi Indonesia) 6, no. 1 (2009): 56-73. https://docplayer.info/ 93995925-Landasan-konseptual-teoritik-psikologik-dari-

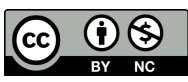


berbagai-teori-inteligensi.html.

Woolfolk, Anita E, and Lorraine McCune Nicolich. Educational Psychology for Teachers. New Jersey: Prentice Hall Inc, 1984.

Zohar, Danah, and Ian Marshall. Spiritual Capital: Wealth We Can Live By. California: Berrett-Koehler Publishers, 2004.

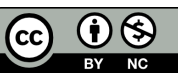

DOI: $10.19105 /$ karsa.v29i1.3379 